\title{
The Effect of Child-Friendly Lift-the-Flap Story Books on the Creative Thinking Ability
}

\author{
E. Kus Eddy Sartono ${ }^{1}$, Eka Irawati²
}

\begin{tabular}{l} 
ARTICLE INFO \\
\hline Article History: \\
Received 05.04.2019 \\
Received in revised form \\
03.10 .2019 \\
Accepted \\
Available online \\
01.12 .2019
\end{tabular}

\begin{abstract}
Child-Friendly Lift-the-Flap Story Books is a textbook with instructional materials integrated into the story and the pictures. This study aims to determine the effect of child-friendly lift-the-flap story books "Kayanya Negeriku" to the students' creative thinking abilities fourth grade. Quasiexperimental research design types of nonequivalent comparison-group design. The research population is fourth-grade students at SDN Pleret Bantul. The cluster random sampling technique was used to determine pre-existing samples without random assignments, so that 28 students in fourth-grade of SDN Pungkuran were obtained as the experimental class and 28 students in fourthgrade of SDN Putren as the control class. Data collection through pretest and posttest using creative thinking test instruments that have been tested for validity and reliability. Data were analyzed using paired samples t-test, gain test and $\mathrm{N}$-gain test. The results showed that child-friendly lift-the-flap story books "Kayanya Negeriku" affects the creative thinking abilities of fourth grade elementary school students.
\end{abstract}

(C) IJERE. All rights reserved

Keywords: ${ }^{1}$ Child-friendly lift-the flap story books, creative thinking ability, elementary school

\section{INTRODUCTION}

Textbooks have an important role in teaching and learning. Textbooks can fulfill the needs of students, providing guidance for novice teachers within courses and design activities, so that textbooks can guarantee the size of the structure, consistency, and the logical progression in a classroom (Mohammadi \& Abdi, 2014: 1148). The statement can be understood that the textbook can be used as a guide to implementing teaching and learning activities in the classroom so that learning becomes more structured. The context of textbooks in elementary schools can encourage students to have high-level thinking skills and facilitate students in information processing (Rupam \& Shalini, 2017: 31). Also besides, according to Novitasari (2018: 9) implementation of child-friendly learning concept can be seen from the teaching materials by following the level of development of learners, referring to the statement can be understood that the use of teaching materials such as textbooks can create a child-friendly learning environment.

To support the achievement of Curriculum 2013 (K-13) and to realize the policy of child-friendly schools, the textbooks used in the study is provided by the Government. But the textbooks provided by the government, particularly textbooks for fourth-grade still has shortcomings. The research result Saraswati et al. (2016) show that there are deficiencies which include 1) aspects of the design of the text message, which is written in the book difficult to read, the words in the book is difficult to understand, serving sentences that are too long; 2) The design aspects of a picture message, the picture in the book is notseen clearly, the picture in the book is difficult to understand, the picture in the book is not interesting, and a combination of text with a background color is less suitable. The results of this study indicate that the shortage of elementary school fourth-grade textbooks provided by the government lies in the aspect of the presentation of text and images. Research Darsono et al. (2018: 1) also states that fourth-grade students in need of textbooks with special specifications such as textbooks presented in the book-based story of character education to help improve the skills of students. It shows that students need textbooks that integrate into the subject matter of children's stories. Overcoming the government through the Minister of Education and Culture No. 8 of 2016 on the books used by educational units allow schools to use textbooks from private publishing of a book or other relevant sources, the book was not pornographic, understand extremism, radicalism, violence, racial, gender bias, and contain no deviations.

One Non-Kemendikbud textbook is widely used in elementary schools is a book published by Erlangga. Not surprisingly, the book is widely used as a companion in learning in schools, according to Purnanto\& Mustadi (2016: 110) showed that when viewed from the aspect language textbooks published by Erlangga eligible for use in learning. One kind of textbooks published by Erlangga which can be a means of supporting K-13 learning in fourth grade is an integrated thematic book Kayanya Negeriku (4i). The quality of the illustrations in this book can be tempting readers because it uses colors diverse (Ayu \& Riyadhi, 2014:

Corresponding e-mail:pjj_kusedisartono@yahoo.com 1, ekairawati.2017@student.uny.ac.id 2

Orcid Kode: orcid.org/0000-0003-2819-2203 1, orcid.org/0000-0003-1436-6719 2

Lecture of Pendidikan Dasar Yogyakarta State University ${ }^{1}$, Student Magister of Pendidikan Dasar Yogyakarta State University ${ }^{2}$ 
190). The book is presented by following K-13 textbooks issued by the government, containing the title of the theme, the subject matter of integrated, practice questions and mapping basic competence. Also besides, various activities are contextual and fun to support the learning process towards the achievement of attitudes, skills, and knowledge by following core competence and basic competences in K-13.

In addition to the Erlanggga publication of textbooks, one textbook innovation that can be used to support learning in K-13 is child-friendly lift-the-flap story books. Child-friendly lift-the-flap story books included in innovative learning resources and is the product of research conducted by Sartono et al. (2018) and has fulfilled the eligibility and validity indicator, so it can be used in the learning process. Child-friendly lift-the-flap story books made by following the development of the ability of elementary school-age students from various aspects, such as images, storylines, and other content. Child-friendly lift-the-flap story books also includes learning materials, encouraging students to conduct scientific activities in learning and stimulates children to read, because of the highlight color, text, and an interesting illustration. Child-friendly lift-the-flap story books has several advantages when compared to other textbooks, namely employing the concept of "lift the flap" or there is a window/lid that can be opened and closed by integrating stories and pictures. According to Pourrajab \& Rabbani (2015: 83) indicates that the image on the textbook of elementary school students can improve the imagination of the students so that the creativity of students also increased. Stories and images contained in child-friendly lift-the-flap story books made contextually appropriate to the theme in K-13 and the daily life of students, be a differentiator which is owned by the book child-friendly lift-the-flap story books compared with the textbooks that had been used by students in the school, so as to facilitate the learning of thematic integrative in fourth grade and provide facilities for students to learn and understand the subject matter. This is in line with Pratiwi (2017: 194) which states that the books are developed based on local culture and appropriate learning for K-13 is effective as a companion book learning in the classroom and can bring a positive change in the aspect of students' attitudes. Additionally, Purwanti et al. (2019: 65) also states that elementary school fourth-grade students require the subject matter with a locally-based context by following the environment of the everyday life of students. It shows that child-friendly lift-the-flap story books can be used in learning because it meets the needs of students in learning.

Another advantage of child-friendly lift-the-flap story books is its story which contains a moral message about child-friendly as the importance of mutual respect differences in peers and society, nondiscrimination, care for the natural environment, and discipline (Meylana, et al., 2019). The statement can be understood that by using this book is not only to attract the attention of students to learn but with the concept of child-friendly can also create a mental state that pleasant because of the stories in the book makes students feel happy, comfortable and safe when participating in learning activities. Child-friendly lift-theflap story books contains material that matches the theme 9 "Kayanya Negeriku" equipped with open-ended questions and crossword puzzles that can encourage students to think more broadly, deeply and bring new ideas (Oktavia, 2018). Use child-friendly lift-the-flap story books in learning to create a pleasant learning environment and is expected to help students understand the learning material more quickly because it can realize real child-friendly lift-the-flap story books abstract material, as well as a child-friendly story, can make students feel safe, comfortable and enjoyable. Thus, indirectly child-friendly lift-the-flap story books can stimulate students to be ready to learn and encourage learners to spend more new ideas because the material is presented by following students' everyday conditions in the surrounding environment. When the students are ready to learn, then will allow the child to understand the material to develop the cognitive and affective abilities of students, especially in the aspect of creative thinking ability of students is an ability to be owned by the students in the face of life in the $21^{\text {st }}$ century and the output of the learning curriculum 2013.

Child-friendly lift-the-flap story books is assumed to facilitate students to have creative thinking skills. According to Markamah et al (2019), the use of textbooks compiled in integrative thematic concepts can develop the creativity of students. The statement can be understood that students' creative thinking skills can be optimized through the use of textbooks, child-friendly lift-the-flap story books is a textbook presented by integrative thematic. Creative thinking is a part of high-level thinking and is the highest level of cognitive ability (Anderson \& Krathwohl, 2001:84). Creative thinking is the ability to think to cultivate and form existing elements, into a new pattern or structure (Arends \& Kilcher, 2010:233). Meanwhile, according to Johnson (2009: 214), Creative thinking is a thought of the outcome of noticing intuition, animating imagination, revealing new possibilities, unlocking amazing viewpoints, and raising ideas that are not 
unexpected. So creative thinking is a process that is used when we bring or bring up a new idea, giving birth to something new or real quality work. There are four creative thinking indicators, namely fluency, flexibility, originality and elaboration (Kaufman, Plucker, \& Baer, 2008:17). The creative thinking abilities of students can be triggered via cognitive activities assigned by the teacher through a variety of challenging assignments. According to McGregor (2007: 36-37), creative thinking skills can be taught how to give the task openly and challenge students to be able to think, to motivate students to use something they already know, offer the opportunity to work in collaborative groups, and encourage students to can communicate the task to be done, as well as creating learning outcomes at different levels. Through such learning, creative thinking students will look when they like to learn new things, enjoy working together in groups, communicate the results of the task has been accomplished, and have created the idea of the students themselves. However, based on the results of observations in the field it shows that students' creative thinking skills still need to be optimized because the average student has difficulty in solving HOTS type problems, difficulty answering questions with their sentences and cannot provide detailed answers. Based on the explanation above, childfriendly lift-the-flap story books can be a solution to optimize students' creative thinking abilities. In a previous study based on the child-friendly lift-the-flap story books, according to experts has been declared eligible to be used to stimulate creative thinking abilities of students but there is no empirical evidence supporting the feasibility results. Therefore, researchers wanted to determine the effect of child-friendly liftthe-flap story books on the creative thinking abilities elementary school fourth-grade students. In this study, child-friendly lift-the-flap story books "Kayanya Negeriku", will be compared with the integrated thematic books Erlangga "Kayanya Negeriku".

\section{Situation of the Problem}

Teachers require their other companion book, to provide guidance in implementing the learning activities and deepen the learning material, as well as the creative thinking abilities of students still need to be optimized.

\section{Aim of the Study}

This study aims to determine the effect of child-friendly lift-the-flap story books "Kayanya Negeriku" of the creative thinking abilities of fourth-grade students of elementary school.

\section{METHOD}

This study is quasi-experimental research, design nonequivalent comparison-group design, According to Johnson \& Christensen (2014: 485-486) is a quasi-experimental research design experiments that do not provide complete control of potential confounding variables. It shows that in practice there were no randomization students into a new class, so in this study carried out by utilizing an existing class of students. In this research are class experiment and class control, which together receive pretest, treatment, posttest.

\begin{tabular}{|c|c|c|c|}
\hline \multirow[b]{2}{*}{ Eksperiment } & Pretest & Treatment & Posttest \\
\hline & $\mathrm{O}_{1}$ & $\mathrm{X}_{1}$ & $\mathrm{O}_{2}$ \\
\hline & \multicolumn{3}{|c|}{ 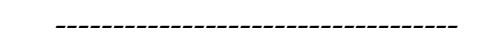 } \\
\hline Control & $\mathrm{O}_{1}$ & $\mathrm{X}_{2}$ & $\mathrm{O}_{2}$ \\
\hline
\end{tabular}

Figure 1. Design Research Nonequivalent comparison-group design

\section{Material}

The population in this study was fourth-grade students from 14 elementary schools in the district of Pleret Bantul consisting of male and female students with an average age of 10 years. Determination of the sample using cluster random sampling technique is based on the reason that it is homogeneous based on academic ability, both accredited and using the curriculum in 2013, in order to obtain a research sample of 56 fourth-grade students consisting of 27 male students and 29 female students from SDN Pungkuran as classes experiment used a child-friendly lift-the-flap story books and SDN Putren as classes control used the integrated thematic book published by Erlangga. Each class uses four different textbooks for 4 meetings, in 
learning theme 9 "Kayanya Negeriku", sub-theme 1 "Kekayaan Sumber Energi di Indonesia" learning 1 and 3, and sub-theme 2" Pemanfaatan Kekayaan Alam di Indonesia" learning 1 and 3. The instrument used in this study was a creative thinking test instrument that had been tested for validity and reliability.

\section{Data Analyses}

The collection of data obtained through the pretest and posttest. The data have been collected first tested the prerequisite form of normality and homogeneity test. After that, then conducted a descriptive analysis and hypothesis testing. Statistical techniques were used in the descriptive analysis include the mean, variance, standard deviation, intending to define the data which have been obtained with the words clearer and detailed. Furthermore, there are two statistical tests were used to test the research hypothesis. First, test paired samples t-test was used to test the effect of the use of the book. Second, the data test gain and N-gain used to test the hypothesis of an increase in pretest and posttest learning outcomes.

\section{FINDINGS}

The test results indicate that the data prerequisite pretest and posttest creative thinking abilities of students have met the criteria of normal and homogeneous, so the hypothesis testing using a paired samples $\mathrm{t}$-test can be done. The test results paired samples t-test using the data pretest and posttest creative thinking skills can be seen in Table 1 below;

Table 1. Results of paired samples t-test Creative Thinking Ability

\begin{tabular}{clcccc}
\hline No. & \multicolumn{1}{c}{ Data } & $\mathrm{t}$ & $\mathrm{dF}$ & Sig. (2-tailed) & Keterangan \\
\hline 1. & $\begin{array}{l}\text { Pair 1 } \\
\text { Pretest }- \text { posttest Child-Friendly }\end{array}$ & -10.719 & 27 & 0.000 & $<0.05$ \\
& & & & Ho refused and Ha accepted \\
Lift-the-Flap Story Books & & & & \\
2. & $\begin{array}{l}\text { Pair 2 } \\
\text { Pretest - posttest integrated } \\
\text { thematic book published by }\end{array}$ & & & & Ho refused and Ha accepted \\
& Erlangga
\end{tabular}

Both books were used in the study showed an influence on students' creative thinking abilities in fourth grade. Under these conditions, do gain and $\mathrm{N}$-test to determine the influence of the gain resulting from the third book through the data value pretest and posttest. Test gain and N-gain are done SPSS 25 for windows. The results of the test gain and $\mathrm{N}$-gain is as follows.

Table2. Test Results N-gain gain and Creative Thinking Ability

\begin{tabular}{|c|c|c|c|}
\hline No. & Class Treatment & gain & $N$-gain \\
\hline 1. & Child-Friendly Lift-the-Flap Story Books & 24.22 & 0.48 \\
\hline 2. & $\begin{array}{l}\text { Integrated thematic book published by } \\
\text { Erlangga }\end{array}$ & 19.08 & 0.40 \\
\hline
\end{tabular}

Based on table 2, it shows that the gain value in the class using the child-friendly lift-the-flap story books gets the highest value, which is 24.22 , while the class using the integrated thematic book Erlangga only gets a value of 19.08 . When viewed from the $\mathrm{N}$-gain values, classes using the child-friendly lift-the-flap story books also scored the highest, amounting to 0.48 , while the class by using the integrated thematic books Erlangga only obtains a value of 0.40 . Increasing the value of these two classes based on criteria Ngain indicates an increase in the medium category. This gain and N-gain test shows that although the two books used have the same effect on creative thinking abilities, the class using the child-friendly lift-the-flap story books gives a higher increase in pretest and posttest, so it can be said that child-friendly lift-the-flap story books is more influential on the creative thinking ability of fourth grade students, than the class using integrated thematic books Erlangga. 


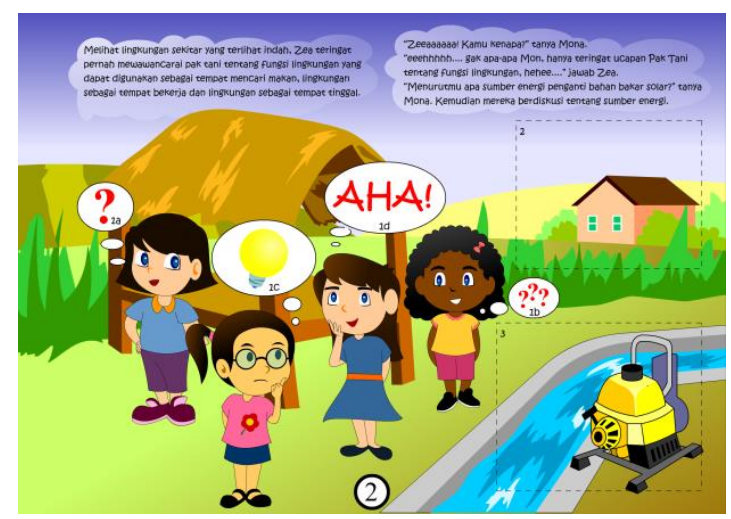

Figure 2. The front page of the lift the flap

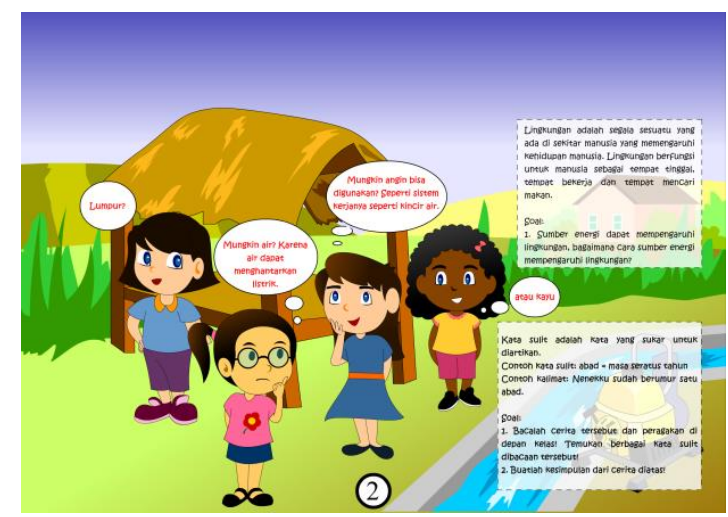

Figure 3. The backyard lift the flap

\section{RESULT, DISCUSSION, AND SUGGESTIONS}

The results showed that the use of a child-friendly lift-the-flap story books "Kayanya Negeriku" in the learning process can affect students' creative thinking abilities in fourth grade. The test results from the use of integrated thematic books Erlangga also shows there is an influence on students' creative thinking abilities in fourth grade. However, when viewed from an increase in the average value of creative thinking abilities of students per class at the learning theme 9 "Kayanya Negeriku", a class using the child-friendly lift-the-flap story books sees a higher average value is higher than the other two learning books.

The use of a child-friendly lift-the-flap story books can make learning more interesting. This was revealed by Blaine \& Rule (2017: 16)stating that lifts the flap attractive to students and motivates students to focus their attention. The statement can be interpreted that the book with the concept of lift the flap can make learning more interesting and motivate students to focus on learning material. Not only has the concept of a lift the flap to attract and motivate students, but another reason lift flap storybook based childfriendly can affect students' creative thinking abilities is the picture storybook concept that combines the material, stories, and pictures. This is in line with the results of research Loh (2016: 5), which showed that the combination of topics, stories, and pictures to stimulate the emergence of ideas, imagination, and curiosity of students. It is strengthened by Yang et al. (2016: 1) which shows that by giving students the chance to interact directly with the picture books to learning, can enhance the creative thinking of students. This means that creative thinking abilities students may increase if students are directly involved in learning activities. So that students can play an active role in the learning activities, the content contained in the book should be able to attract the attention of students, motivate students to learn and facilitate students to stimulate their creative thinking abilities.

When the child-friendly lift-the-flap story books was introduced and used in the study, students were very interested to know and read the contents of the book. This happens because of the child-friendly lift-the-flap story books based comply book component for elementary students. As proposed by the Lin (2012: 40-41) the research shows that in preparing the book for elementary students there are components that need to be considered, such as mature illustration, 3D feeling, color combination and innovative content, specifically for students 4th grade, they are more interested in learning to use picture books accompanied by text too long. Overall child-friendly lift-the-flap story books has met these components. The concept of a mix 
of images and text in a storybook lifts the flap can also provide benefits for students, such as the results of research conducted by Mayer \& Moreno (2003: 49) that the combination of text and images can reduce the cognitive load of students. It can be understood that when the stories and images are placed on the same page, students can immediately see a visual story told, to ease the burden and the student's mind when learning. The statement was reinforced by Heath et al. (2014)adding that the pictures can help children to increase their interest in something they read so that students' perceptions will be easier to be affected even though they do not see concrete form. Agrees with both the previous statement, Saccardi (2014: 37) also expressed his opinion, that the combination of text and images on a picture book can help students become more alive to the world around them and to imagine new ways to interact with it. It also shows that the image and text stories contained in the child-friendly lift-the-flap story books can lead students to be able to think creatively by imagining new ideas when interacting directly with the environment around them.

In addition to the factors mentioned above, the activities contained in the lift flap storybook based child-friendly can also facilitate the process of creative thinking of students. Syntax activities in childfriendly lift-the-flap story books consists of group activities, reading stories, opening a window (lift the flap) in accordance with the sequence numbers, expressing an opinion about the stories that have been read, roleplay, discuss it questions in window lift the flap, read insights, answer crossword puzzle and make the conclusion of each story.According to Wallas (2014), the creative thinking process consists of four stages: preparation, incubation, illumination, and verification. Relating to cultivate students' creative thinking abilities then the process can be carried out in the learning activities. The process of creative thinking in kegiatan contained in the lift the flap story book based child friendly include, 1) preparation, namely by providing opportunities for students to gather knowledge through text stories and images contained on the lift the flap story book based child friendly and asked people else if there is one thing that has not been understood by reading the story, open a window (lift the flap) in accordance with the sequence numbers, and read insights; 2) incubation, ielearning activities lead students seemed to break away from learning for a while, various ideas freely grouped and rearranged without immediately realizing students have been working on the problem through role-playing activities and express opinions about the stories that have been read; 3) illumination,namely the emergence of inspiration or new ideas, as well as the psychological processes that initiate and follow the emergence of inspiration or new ideas is done in group activities, discuss it questions in a window lifts the flap and answer crossword puzzles; 4) verification, that phase to test ideas or creations of students to the realities conducted through making the conclusion of each story. The series of events contained in the lifts the flap storybook based child-friendly, can facilities students in the process of creative thinking, and finally, affect the creative thinking abilities have increased. Research result Maharani \& Waluya (2017), as well as Mardianti \& Wijayanti (2018) also showed that the four stages of creative thought processes triggered by Wallas, namely preparation, incubation, illumination, and verification can enhance creative thinking of students, so that students can solve various problems faced in learning, finding the right solution and check to verify an idea tau the idea first before drawing a conclusion.

Influential child-friendly lift-the-flap story books "Kayanya Negeriku" on the ability of creative thinking of students as well as the concept of child-friendly that shown by the interaction between characters in the story, such as it does not contain elements of discrimination, does not contain elements of violence, does not contain elements degrading, the story is presented by integrating contextual material in accordance with the environment and everyday life of students, encourage active participation of students in learning, and present learning materials in accordance with the level of development of students. It is strengthened by Sartono et al. (2018) which shows that shows that in addition to containing material and exercises, childfriendly lift-the-flap story books also contains illustrations and stories. The story is presented associated with moral values about child-friendly as the importance of mutual respect for difference peers and society, non-discrimination, care for the natural environment, and discipline. It shows that child-friendly lift-the-flap story books learning resources to create a child-friendly learning environment, which can affect students' ability to think creatively. As for where a statement Khalilolahi et al. (2015) shows that the concept of a childfriendly environment can encourage the emergence of creative thinking. Referring to the statement indicates that the creative thinking abilities can be created through child-friendly learning. Child-friendly lift-the-flap story books to facilitate the implementation of the learning process.

Based on the translation of the above it can be concluded that lifts the flap storybook based childfriendly "Kayanya Negeriku" effect on students' creative thinking abilities fourth grade. It shows that child- 
friendly lift-the-flap story books to attract the attention of students, motivating students to learn, to facilitate the process of creative thinking, and create learning child-friendly so that students truly can think creatively with the high category, which is shown by the results creative thinking ability tests. There are various other factors that cannot be conditioned by researchers, including student characteristics, student psychology, or diverse student learning styles, so it is expected to open up opportunities for further researchers to carry out similar research by taking into account the limitations of existing research in order to obtain more results good again in order to increase scientific insight.

\section{REFERENCES}

Anderson, L.,\& Krathwohl, D. (2010). A taxonomy for learning, teaching, and assessing: a revision of bloom 's taxonomyof educational objectives. London: Addison Wesley Longman.

Arends, R.I. \& Kilcher, A. (2010). Teaching for student learning: become an accomplished teacher. New York: Routledge.

Ayu, L., \& Riyadhi, N. (2014). Kualitas ilustrasi buku teks tematik terpadu tema "keluargaku" jilid 1d terbitan erlangga. Jurnal Publipreneur, 2 (4), 176-190. Retrieved from https://polimedia.academia.edu/publipreneur.

Blaine, D. A., \& Rule, A. C. (2017). E cosystem food web journal of stem arts , crafts, and constructions. Journal of STEM Arts, Crafts, and Constructions, 2(1), 16-31. Retrieved from https://eric.ed.gov/?id=EJ1151173

Darsono, et al. (2018). The need textbook writing of children's story based on character education. International Journal of Educational Research Review (IJERE), 3(2), 1-8.

Heath, P., Houston-Price, C., \& Kennedy, O. (2014). Let's look at leeks! Picture books increase toddlers' willingness to look at, taste and consume unfamiliar vegetables. Frontiers in Psychology, 5, 191.https://doi.org/ 10.3389/fpsyg.2014.00191

Johnson, E.B. (2009). Contextual teaching \& learning: Menjadikan kegiatan belajar-mengajar mengasyikkan dan bermakna. (Terjemahan Ibnu Setiawan). Bandung: MLC (Edisi asli diterbitkan tahun 2002 oleh Corwin Press, Inc.Thousand Oaks)

Johnson, R.B., \& Christensen, L. (2014). Educational research quantitative, qualitative, and mixed approach (5 th ed.). Thousand Oaks: Sage Publications.

Kaufman, J.C., Plucker, J.A., \& Baer, J. (2008). Essentials of creativity assessesment. New York: Wiley.

Khalilolahi, A., Qaffari, A., \& Hosseini, A. (2015). Promoting children's creativity through designing urban environments. European Online Journal of Natural and Social Sciences, 3(3), 801-814. Retrieved from http://european-science.com/eojnss_proc/article/view/4573

Lin, R. (2012). A study of creative thinking for children for children's picture book creation. Procedding ofInternational Conference on Future Computer Supported Education, 2,36-42. https://doi.org/10.1016/j.ieri.2012.06.048

Loh, E. K. Y. (2016). Picture storybooks in teaching chinese as a second language. Comparative Literature and Culture, 18(2). Retrieved from http://docs.lib.purdue.edu/clcweb/vol18/iss2/

Maharani, R., \& Waluya, B. (2017). Creative thinking process based on wallas model in solving mathematics problem. International Journal on Emerging Mathematics Education, 1(2), 177-184. Retrieved from http://journal.uad.ac.id/index.php/IJEME/article/view/5783

Maharani, R., \& Waluya, B. (2017). Creative thinking process based on wallas model in solving mathematics problem. International Journal on Emerging Mathematics Education, 1(2), 177-184. Retrieved from http://journal.uad.ac.id/index.php/IJEME/article/view/5783.

Markamah,E.S., Slamet,S.t.Y., Rukayah, Winarni,R. (2019). Developing appreciative literature textbook based on thematic integrative through active learning. International Journal of Educational Research Review (IJERE),4(3),395-402.

Mayer, R. E., \& Moreno, R. (2003). Nine ways to reduce cognitive load in multimedia learning. Educational Psychologist, 38(1), 43-52. https://doi.org/10.1207/S15326985EP3801_6

McGregor, D. (2007). Developing thinking; developing learning: a guide to thinking skills in education. Thousand Oaks: McGraw-Hill Education.

Meylana, D. A. ., Pujiastuti, P. ., \& Sartono, K. E. (2019). Lift the flap story book based on child-friendly: improving the ability of students mathematical connection Lift the flap story book based on child- 
friendly: improving the ability of students mathematical connection. In International Conference on Mathematics and Science Education (ICMScE 2018). https://doi.org/10.1088/1742-6596/1157/4/042065

Mohammadi, M., \& Abdi, H. (2014). Textbook evaluation: A case study. Procedia - Social and Behavioral Sciences, 98(1994), 1148-1155. https://doi.org/10.1016/j.sbspro.2014.03.528

Novitasari, A.R. (2018). Implementasi pembelajaran dengan konsep ramah anak di sd muhammadiyah pogram khusus kottabarat. Universitas Muhammadiyah Surakarta: Surakarta.

Oktavia, Winda. (2018). Lift the flap story book berbasis ramah anak. Yogyakarta: Universitas Negeri Yogyakarta.

Purnanto, A., \& Mustadi, A. (2016). Analisis kelayakan bahasa dalam buku teks tema 1 kelas I sekolah dasar kurikulum 2013. Profesi Pendidikan Dasar, 3(2), 102-111.https://doi.org/10.23917/ppd.v3i2.2773

Pourrajab, M., \& Rabbani, M. (2015). Effects of pictures in textbooks on students. Multi Disciplinary Edu Global Quest (Quarterly), 2, 83-96. Retrieved from https://www.mdegq.com/archive/volumewise? volume $=877$

Pratiwi, N. L. M. T. (2017). Pengembangan buku cerita anak dengan menginsersi budaya lokal dalam tema kegemaranku untuk kelas i sekolah dasar. Jurnal Ilmiah Pendidikan dan Pembelajaran PPs Universitas Pendidikan Ganesha ISSN 1858 - 4543, 1, 185-195. Retrieved from https://ejournal.undiksha.ac.id/index.php/JIPP/article/view/11984/0

Purwanti,D., Gunarhadi \& Musadad,A.A. (2019). The effect of local-based 2013 curriculum implementation on students' environmental awareness. International Journal of Educational Research Review (IJERE),4(1),65-75.

Republik Indonesia.(2016). Peraturan Menteri Pendidikan dan Kebudayaan Nomor 8 Tahun 2016 Tentang Buku yang digunakan oleh Satuan Pendidikan. Kementerian Pendidikan dan Kebudayaan. Jakarta.

Rupam, M., \& Shalini, P. (2017). Elementary school science textbooks: A framework for analysis. International Education and Research Journal, 2016-2017. Retrieved from http://ierj.in/journal/index.php/ierj/article/view/1257

Saccardi, M. (2014). Creativity and Children's Literature. Santa Barbara: ABC-CLIO.

Saraswati, et al. (2016). Analisis buku teks siswa kurikulum 2013 ditinjau dari aspek desain pesan pembelajaran kelas IV sekolah dasar. e-Journal Edutech Universitas Pendidikan Ganesha Jurusan Teknologi Pendidikan, 5 (2).

Sartono, K. E., Pujiastuti, P., \& Meylana, D. A. (2018). The child-friendly-based lift the flap story book : does this media affect the students ' academic self-efficacy in mathematics learning ?Journal of Education and Practice, 9(24), 97-102.https://doi.org/10.1088/1742-6596/1157/4/042065

Wallas, G. (2014). The art of thought. England: Solis Press.

Yang, C.-H., Cheng, J.-C., \& Chou, M.-J. (2016). Empowering children's creativity with the instruction of wordless picture books. European Journal of Research and Reflection in Educational Sciences, 4(7), 1-16. 